\title{
Evaluating the Application of Food Safety in the Sailing Floating Restaurants in Egypt and its Impact on Customer Satisfaction: Case Study: Luxor and Aswan Floating Restaurants \\ Ahmed Mohamed Atef Ibrahim El-Sayed Ramadan \\ Higher Institute for Specific Studies, Giza
}

\begin{abstract}
The sailing floating restaurants (SFR) are new phenomenon for dining out in Egypt, where consumers can be provided not only with a meal but also with an enjoyable casual dining experience with unrivalled views of the Nile. The research objectives are to evaluate food safety application in Egypt, to identify customers perceptions of the floating restaurants sailing down the Nile and to explore the different attributes that influence customer satisfaction. A Food safety evaluation survey is applied in 12 sailing floating restaurants as a sample of floating restaurants representing 14\% of total restaurants of this type in Luxor and Aswan, An Interview with managers of sailing floating restaurants and Customers Food Safety Checklist, 300 checklists were distributed to measure the customers' feedback (SFR). Data was collected by personal visits. The major findings showed that most executive chefs, who are supposed to be the leaders of kitchen in floating restaurants, are holders of unspecialized education certificates. Most of visited floating restaurants do not have food safety policy or even a written food safety operation standard since most executive chefs ignore the significance of such systems and have poor food safety attitudes and practices. Finally, the study suggested the necessity of creating a food safety operational standards and instruction guide in (SFR).
\end{abstract}

Keywords: Sailing Floating Restaurants (SFR), Customer Satisfaction, Food Safety, Food Contamination.

\section{Introduction}

Bowen, 1996) illustrated that, all customers are required to book lunch or dinner in advance. SFRs serve a wide range of food and beverage products where customers can choose from the set menu or select from the ala carte menu, which offers seafood, Lebanese and oriental cuisines, and in a cruise trip which lasts around two hours. Both fixed and sailing floating restaurants are categorized from four stars to five stars and they are affiliated with international chains.

Hwang, 2006) added that, the activities of food handling and the quality of services in the (SFRs) are directly related to employees and owners of food and beverage service establishments. Since they are responsible for managing hygienic-sanitary quality and providing safe food to clients which lead to customer satisfaction. Moreover, food handler education and training are seen as one strategy by which food safety can be increased, offering long-term benefits for the food service industry. Education and training activities closely associated with work environment would be more appropriate than food hygiene courses that are detached from the workplace and there is a need to develop education and training methods that proved to change behavior, attitude, practice as well as imparting knowledge.

It has been observed in the recent period(2000-2018) that there are repeated complaints from the low level quality of food safety provided in floating restaurants and the customers perceptions of the floating restaurants quality is very low.

\section{Research Objectives}

The research objectives are to

1. Evaluate the food safety application in sailing floating restaurants in Luxor and Aswan. 
1.2 Identify customer's perception of the floating restaurants sailing down the Nile in Luxor and Aswan.

1.3 Explore the different attributes that influence customer satisfaction in the sailing floating restaurants.

\section{Review of Literature}

Floating Restaurant Concept

Maeda and Rheem, 2000) defined that a riverside restaurant or a floating restaurant is usually a restaurant built on a large flat steel barge floating on water. Sometimes retired ships are also refurbished and given a second term as a floating restaurant. Is, a restaurant located on a pontoon or on a boat converted for the purpose of cooking and serving meals.

Ohkawa and Kobayashi, 2003) mentioned that there are two types of very large floating structures (VLFSs), namely the semisubmersible-type and the pontoon-type. Semi-submersible type floating structures are raised above the sea level using column tubes or ballast structural elements to minimize the effects of waves while maintaining a constant buoyancy force. Thus they can reduce the wave-induced motions and are therefore suitably deployed in high seas with large waves. In contrast; pontoon-type floating structures lie on the sea level like a giant plate floating on water. Moreover, Moan, 2004) added that Pontoon-type floating structures are suitable for use in only calm waters, often inside a cove or a lagoon and near the shoreline. Large pontoon-type floating structures have been termed Mega-Floats. These Mega-Floats have advantages over the traditional land reclamation solution for space creation in the following respects:

- they are cost effective when the water depth is large (note that the cost of imported sand for land reclamation in some countries has risen significantly and it may come a time that sand may not be even available from neighboring countries),

- Environmental friendly as they do not damage the marine eco-system, or silt-up deep harbors or disrupt the tidal/ocean currents,

- They are easy and fast to construct (components may be made at different shipyards and then brought to the site for assembling) and therefore sea-space can be speedily exploited.

- They can be easily removed (if the sea space is needed in future) or expanded (since they are of a modular form).

- The facilities and structures on Mega-Floats are protected from seismic shocks since they are inherently base isolated,

- They do not suffer from differential settlement due to reclaimed soil consolidation, their positions with respect to the water surface are constant and thus facilitate small boats and ship to come alongside when used as piers and berths.

- Their location in coastal waters provide scenic body of water all around, making them suitable for developments associated with leisure and water sport activities.

\section{Food Quality and Safety}

Food safety is a public health concern. Every year in the United States an estimated of 48 million illnesses, 128,000 hospitalizations, and 3,000 deaths are the consequence of food borne illnesses. In the United States, people are spending approximately $\$ 580$ million on purchasing food from retail foodservice operations. Food consumed at retail foodservice establishments, commercial and noncommercial sectors remain an important source for outbreaks of food borne disease. It is estimated that annually food borne illnesses in retail foodservice operations costs consumers $\$ 6$ 
billion in healthcare costs and loss of productivity. According to the U.S. Food and Drug Administration (FDA, 2004), the top three factors contributing to food borne illnesses in foodservice operations are: a) poor personal hygiene, b) cross contamination, and c) time/temperature control.

Known food borne disease outbreaks have been associated with foods served at commercial and noncommercial retail food stores and foodservice facilities including restaurants, clubs, assisted living facilities, nursing homes, childcare centers, schools, and university foodservice. Most common reasons for food borne illness in Costa Rica are lack of food safety training for food handlers, purchasing from unapproved sources, time-temperature control, cross contamination, and lack of personal hygiene among food handlers (FAO, 2001)

McElroy and Cutter, 2004) illustrated that, food workers play a critical role in ensuring food safety, those who do not practice proper personal hygiene, including hand washing at the appropriate times and using appropriate methods, can contaminate food. The Food and Drug Administration (FDA) report on the occurrence of food borne illness in selected institutional food service, restaurants, and retail food store can be attributed to: improper holding/time, temperature, poor personal hygiene, and contaminated equipment. Studies have found that food safety training is positively associated with self-reported changes in food safety practices (Clayton et al., 2002)

Other studies have found that training helps to improve overall employee knowledge of food safety (Costello et al., 1997; Finch and Daniel, 2005; Howes et al., 1996) although others have found that training is not consistently associated with improved knowledge (Luby et al., 1993; Pilling et al., 2008). Roberts et al., 2008) observed the influence of a food safety information sheet on practices within the foodservice environment. Results showed that the information had a positive impact on food handler behaviors.

Food safety knowledge is important to prevent food borne illness. Prevention of food borne illnesses is one of the primary responsibilities of the foodservice industry (Cushman, et al., 2001). It is the managers' responsibility to ensure the safety of food prepared and served to customers. Retail foodservice operations often produce large quantities of different types of food in the same area, which creates a risk environment for outbreaks of food borne disease. Foods can become contaminated at any link of the food chain, from production to service. Most of food borne illnesses has been linked to foods prepared in retail foodservice operations and caused by human error at some point in the food chain. Identifying foodservice employees' knowledge, attitudes, and practices is essential to assure food safety in retail foodservice operations and prevent the occurrence of food borne illnesses.

\section{Repeat Customers}

A satisfied customer returns to do business with the service provider. (Kamra and Mill, 2002) The satisfaction reinforces positive attitudes toward the brand, leading to greater likelihood that the same brand will be purchased again. According to Ladhari, 2002) if customers are satisfied with a product or brand, they will be more likely to continue to purchase, use it and to tell others about their favorable experience with it (Wie and Strohbehn, 1997). The satisfaction is especially important for companies that rely on repeat business (Hoyer. and Maclnnis, 2007). In the RitzCarlton hotel, service quality has resulted in high customer retention: more than 90 per cent of customers return. Customers usually return to a restaurant because they enjoyed their last experience. 
When the product, the customers receive is different and does not meet their expectations on the next visit, they often do not return, most customers do not complain but they just leave and never come back). Dissatisfied customers`can easily become a lost customer. Dissatisfaction with food service may lead to dissatisfaction with the overall tourism experience and would be a substantial reason for tourists not returning to a destination. About 63 percent of unhappy customers who do not complain take their business elsewhere, quite often permanently. (Kotler,et al., 2006).

A satisfied customer will spread a recommendation by word of mouth. On average, one satisfied customer will tell three to five other persons about his business as well (Trooboff et al., 1995). In addition, (Brun, and Morales, 2008) stated that a positive and significant relationship exist between satisfaction and recommendation. In service industries such as restaurant services, positive word of mouth communications is considered as a critical factor of success (Pizam and Ellis., 1999).

Customers are likely to tell more their friends about the bad service they receive than about the good service they get. People love to talk and will normally talk more about a bad experience or bad service than they talk about anything good that occurred (Wade, 2006). Customers may complain to others about poor service quality and refuse to patronize the service in the future (Hensley and Sulek, 2007).

\section{Drivers of Customer Satisfaction}

Waller,1996) mentioned that, the factors that which cause customer satisfaction are usually in the human factors and behavioral group or timelines group, for examples, the courteous behaviors of the front desk attendant in a hotel or a minimal waiting time to be seated in a restaurant. The Factors that cause customer dissatisfaction are queuing, ignorance, rudeness, and indifference .Moreover, Law and Hui , 2004) added that, to improve customer satisfaction and loyalty, companies must understand what factors influence customer satisfaction and repurchase behavior, and then try to make improvements in these critical areas so that they can have more satisfied and loyal customers

Lee, 2002) illustrated that; food quality came out as the only one of nine factors being tested that had a significant effect on intent to return for 239 diners at an Irish-pup style full-service restaurant in the southeastern United States. The restaurant's atmosphere and the fairness of the seating procedures also had significant effects. Sometimes, what a customer really wants is a satisfying meal at a full-service restaurant. Of course, good food is an essential component of a "satisfying meal". However, good service and pleasant setting are also important in a full-service restaurant. For the entire component in a full-service restaurant, food quality is perhaps the single most important factor. Customers in a full-service restaurant may sit for a relatively long time, making seating comfort another important aspect of the physical setting.

Threevitaya, 2003) concluded that, the factors that which influence the decisions of customers to dine at selected restaurants including hygienic or cleanliness, quality of the food, taste of the food, freshness of the ingredients, value for money, price and service also atmosphere of the restaurant. Sulek and Hensley, 2004) added that performance is a major key for satisfaction after they investigated the impact of expectations, performance, and disconfirmation on satisfaction. The service quality is an antecedent of customer satisfaction, customer satisfaction has a significant impact on intention to purchase, and service quality has less impact on intentions to purchase.

The following eight factors are the most important for most people to select restaurants: location; menu item differentiation; price acceptability; lighting; décor; potion sizes; product 
quality; service standards; and menu diversity (The principles that managers should follow to meet or exceed customer expectation, such as employee greeting, restaurant atmosphere, speed of service, and convenience. Other studies have identified numerous factors that influence customer satisfaction with a dining experience, including waiting time, quality of service, responsiveness of front-line employees, menu variety, food prices, food quality, food-quality consistency, ambience of the facilities, and convenience (Gupta et al., 2007)

\section{Customer Satisfaction Measurement \\ Customer satisfaction formulas}

In this formula $(\mathrm{S}=\mathrm{P}-\mathrm{E})$, 'S' stands for satisfaction, 'P' for perception and 'E' for expectation as satisfaction $=$ perception - expectation. If customer expects a certain level of service and perceives it higher, he is satisfied customer. If he perceives the same level as before, but expected higher, he becomes disappointed and, consequently, a dissatisfied customer (Maister, 1985; Bateson., 1995,; Maylor, 2001).

Parasuraman et al., 1985) mentioned that, service quality should be measured by subtracting customer's perception scores from customer expectation scores $(\mathrm{Q}=\mathrm{P}-\mathrm{E})$. The greater the positive score represents the greater the positive amount of service quality. The gap that may exist between the customers' expected and perceived service is not only a measure of the quality of the service, but is also a determinant of customer satisfaction/ dissatisfaction (Pizam, and Ellis, 1999. In general, according to Maister, 1985), the gap between the perception and expectation for waiting experience determines the customer satisfaction with waiting.

\section{Methodology}

Food safety evaluation is implemented particularly for kitchen because they handle food through four critical stages: receiving food from stores, preparing food for cooking, cooking food and storing cooked food for service. Food safety evaluation is applied in 12 sailing floating restaurants as a field survey sample representing 14\% of total in Luxor and Aswan sailing floating Restaurants. The research utilizes two analytical tools.

- Interview with the Mangers and the Executive Chefs: The purpose of this interview is to measures the qualification of chefs and evaluates the application of food safety or HACCP system in the investigated SFR. It also estimates the effectiveness of food safety training courses. The 14 questions directed to the executive chefs of the visited hotels. : Data collected by only personal visits, Sample selection considers variation in geographical distribution and classification.

- Food Safety Checklist: 300 food Safety Checklist forms were distributed to customers, to measure the customer's feedback about the food safety in sailing floating Restaurants.

The grade level is utilized in the research to be the measurement system for providing the final evaluation of both food safety checklists. The grade level for the checklist is calculated by the $\%$ of frequently positive answers. The grade level for the test is calculated by the $\%$ of total correct answers and points obtained as follows:

- Excellent:90-100\%

- Acceptable: 75-89\%

- Neutral:50-74\%

- Not Acceptable: 25-49\%

- Poor: Less than $25 \%$ 


\section{Analysis}

Results were subjected to one-way analysis of variance (ANOVA) of the general liner model (GLM) using SAS (1999) statistical package. The results were the average of three experiments $(\mathrm{p} \leq 0.05)$.are tabulated to prove ease of analysis.

Table 1: Results of the interview

\begin{tabular}{|c|c|c|c|c|}
\hline Ser. & Food Safety Criterion & Yes & No & LSD \\
\hline 1 & Checking the temperature of incoming food items & $100^{\mathrm{b}} \pm 5.7$ & $200^{\mathrm{a}} \pm 5.8$ & 22.7 \\
\hline 2 & $\begin{array}{l}\text { Freshly cooked food that will be used later is rapidly cooled } \\
\text { in a fridge at } 5^{\circ} \mathrm{C} \text { or colder }\end{array}$ & $130^{\mathrm{b}} \pm 2.9$ & $170^{\mathrm{a}} \pm 4.0$ & 13.8 \\
\hline 3 & $\begin{array}{c}\text { Freshly cooked food are stored at } 63^{\circ} \mathrm{C} \text { or hotter if it is to be } \\
\text { served }\end{array}$ & $140^{\mathrm{b}} \pm 2.5$ & $160^{\mathrm{a}} \pm 2.9$ & 12.5 \\
\hline 4 & $\begin{array}{c}\text { Covering and storing cooked food immediately before } \\
\text { serving }\end{array}$ & $135^{\mathrm{b}} \pm 2.9$ & $165^{\mathrm{a}} \pm 5.8$ & 17.9 \\
\hline 5 & $\begin{array}{l}\text { Using digital probe thermometers to test core food } \\
\text { temperature, and cleaning and disinfecting probes } \\
\text { thoroughly between each use }\end{array}$ & $145^{\mathrm{a}} \pm 5.7$ & $155^{\mathrm{a}} \pm 5.8$ & 22.7 \\
\hline 6 & $\begin{array}{l}\text { Washing hands before and after touching raw and cooked } \\
\text { food }\end{array}$ & $180^{\mathrm{a}} \pm 4.0$ & $\begin{array}{l}120^{\mathrm{b}} \pm \\
11.5\end{array}$ & 34.0 \\
\hline 7 & Using separate equipment for raw and cooked foods & $147^{\mathrm{a}} \pm 4.0$ & $153^{\mathrm{a}} \pm 1.7$ & 12.2 \\
\hline 8 & $\begin{array}{l}\text { Using protective clothing and a cap (hair restraint) when } \\
\text { touching or distributing unwrapped foods }\end{array}$ & $170^{\mathrm{a}} \pm 5.8$ & $130^{\mathrm{b}} \pm 8.7$ & 28.9 \\
\hline 9 & Wearing a clean uniform, when working in food production & $190^{\mathrm{a}} \pm 2.9$ & $110^{\mathrm{b}} \pm 5.8$ & 17.9 \\
\hline 10 & Cleaning and sanitizing work surfaces after each task & $185^{\mathrm{a}} \pm 2.9$ & $115^{b} \pm 2.8$ & 11.3 \\
\hline 11 & Keeping work area and equipment clean all working time & $130^{\mathrm{b}} \pm 2.8$ & $170^{\mathrm{a}} \pm 2.4$ & 10.4 \\
\hline 12 & $\begin{array}{l}\text { Checking safety conditions of foods (expiry date, } \\
\text { temperature, shape, smell and flavor) before cooking food }\end{array}$ & $120^{\mathrm{b}} \pm 5.2$ & $180^{\mathrm{a}} \pm 2.8$ & 16.5 \\
\hline 13 & $\begin{array}{l}\text { Testing food away from pans and dishes and not using finger } \\
\text { while testing food }\end{array}$ & $133^{\mathrm{b}} \pm 1.7$ & $167^{\mathrm{a}} \pm 4.0$ & 12.2 \\
\hline 14 & $\begin{array}{l}\text { Using clean spoon when testing food and cleaning it after } \\
\text { each use }\end{array}$ & $166^{\mathrm{a}} \pm 3.5$ & $134^{\mathrm{b}} \pm 2.3$ & 11.6 \\
\hline
\end{tabular}

Means followed by different subscripts within row are significantly different at the $5 \%$ level Concerning checking the temperature of incoming food items, data presented in Table (1) shows that, the mean numbers of kitchen staff who said yes were 200 people while those who said no while are 100 people, with significant differences between them.

Regarding checking the freshly cooked food that will be used later is rapidly cooled in a fridge at $50 \mathrm{C}$ or colder, data presented in Table (1) shows that, the mean numbers of kitchen staff who said yes were 130 people while those who said no were 170, with significant differences between them.

on the topic of checking freshly cooked food which are stored at $63 \mathrm{C}$ or hotter, data presented in Table (1) shows that, the mean numbers of Kitchen staff who said yes were 140 people while those who said no were 160, with significant differences between them.

Regarding the using digital probe thermometers to test core food temperature, and cleaning and disinfecting probes thoroughly between each use, the mean numbers of Kitchen staff who said yes were 145 people while those who said no were 155 people, with no significant differences between them. 
Concerning washing hands before and after touching raw and cooked food, data presented in Table (1) shows that, the mean numbers of Kitchen staff who said yes were 180 people while those who said no were 120, with significant differences between them.

Regarding using separate equipment for raw and cooked foods, the mean numbers of kitchen staff who said yes were 153 people while those who said no were 157 people, with no significant differences between them.

On the topic of checking using protective clothing and a cap (hair restraint) when touching or distributing unwrapped foods, data presented in Table (1) shows that, the mean numbers of kitchen staff who said yes were 170 people while those who said no were 130, with significant differences between them.

Regarding wearing a clean uniform, when working in food production, data presented in Table (1) shows that, the mean numbers of kitchen staff who said yes were 190 people while those who said no were 110, with significant differences between them.

By examining Cleaning and sanitizing work surfaces after each task, data presented in Table (1) shows that, the mean numbers of kitchen staff who said yes were 130 people while those who said no were 170, with significant differences between them.

Regarding the issue of keeping work area and equipment clean all working time, data presented in Table (1) shows that, the mean numbers of kitchen staff who said yes were 170 people while those who said no were 130, with significant differences between them.

Whereas, checking safety conditions of foods (expiry date, temperature, shape, smell and flavor) before cooking food, data presented in Table (1) shows that, the mean numbers of kitchen staff who said yes were 120 people while those who said no were 180, with significant differences between them.

Reference to wearing a clean uniform, when working in food production, data presented in Table (1) shows that, the mean numbers of kitchen staff who said yes were 190 people while those who said no 110, with significant differences between them.

Concerning testing food away from pans and dishes and not using fingers while testing food, data presented in Table (1) shows that, the mean numbers of kitchen staff who said yes were 133 people while those who said no were 167, with significant differences between them.

Reference to use clean spoons when testing food and cleaning it after each use, data presented in Table (1) shows that, the mean numbers of kitchen staff who said yes were 166 people while those who said no were 134, with significant differences between them.

\section{Results of food Safety Checklist}

As shown in table (2), it can be seen that the ANOVA test revealed five significant points among the Food safety evaluation categories Points obtained are as follows:

- Excellent:90-100\%

- Acceptable: $75-89 \%$

- Neutral: 50-74\%

- Not Acceptable: $25-49 \%$

- Poor: Less than $25 \%$

\begin{tabular}{|c|c|c|c|c|c|c|c|}
\hline \multicolumn{7}{|c|}{ Table 2: Results of food Safety Checklist } \\
\hline Ser. & Food Safety Criterion & Excellent & Acceptable & Neutral & $\begin{array}{c}\text { Not } \\
\text { Acceptable }\end{array}$ & Poor & LSD \\
\hline
\end{tabular}


International Journal of Heritage, Tourism and Hospitality Vol. (12), No. (1/2), March, 2018 By: Faculty of Tourism and Hotels, Fayoum University

\begin{tabular}{|c|l|c|c|c|c|c|c|}
\hline 1. & Is the cooked food fresh & $30^{\mathrm{c}} \pm 1.7$ & $35^{\mathrm{c}} \pm 2.9$ & $\begin{array}{c}80^{\mathrm{ab}} \pm \\
1.2\end{array}$ & $85^{\mathrm{a}} \pm 2.9$ & $75^{\mathrm{ab}} \pm 2.8$ & 7.6 \\
\hline 2. & Is the waiting time suitable & $35^{\mathrm{c}} \pm 1.1$ & $20^{\mathrm{d}} \pm 0.6$ & $75^{\mathrm{b}} \pm 1.7$ & $80^{\mathrm{b}} \pm 2.3$ & $90^{\mathrm{a}} \pm 3.5$ & 6.6 \\
\hline 3. & $\begin{array}{l}\text { Covering the cooked food } \\
\text { immediately }\end{array}$ & $50^{\mathrm{d}} \pm 1.7$ & $55^{\mathrm{cd}} \pm 2.8$ & $\begin{array}{c}70^{\mathrm{a}} \pm \\
2.9^{-}\end{array}$ & $65^{\mathrm{ab}} \pm 2.3$ & $60^{\mathrm{bc}} \pm 1.7$ & 7.5 \\
\hline 4. & $\begin{array}{l}\text { Using separate equipment for } \\
\text { raw and cooked foods }\end{array}$ & $55^{\mathrm{b}} \pm 2.3$ & $60^{\mathrm{b}} \pm 2.9$ & $85^{\mathrm{a}} \pm 2.8$ & $45^{\mathrm{c}} \pm 2.9$ & $55^{\mathrm{b}} \pm 4.0$ & 9.6 \\
\hline 5. & $\begin{array}{l}\text { The staff using gloves when } \\
\text { touching or serving foods. }\end{array}$ & $57^{\mathrm{c}} \pm 1.2$ & $63^{\mathrm{b}} \pm 1.7$ & $76^{\mathrm{a}} \pm 1.7$ & $50^{\mathrm{d}} \pm 1.7$ & $54^{\mathrm{cd}} \pm 2.3$ & 5.6 \\
\hline 6. & $\begin{array}{l}\text { The staff using protective } \\
\text { clothing and a cap (hair } \\
\text { restraint) when touching or } \\
\text { distributing foods }\end{array}$ & $58^{\mathrm{b}} \pm 2.3$ & $52^{\mathrm{c}} \pm 1.5$ & $77^{\mathrm{a}} \pm 1.7$ & $63^{\mathrm{b}} \pm 1.7$ & $50^{\mathrm{c}} \pm 1.5$ & 5.3 \\
\hline 7. & $\begin{array}{l}\text { The staff Wearing clean } \\
\text { uniform, when working in food } \\
\text { service }\end{array}$ & $80^{\mathrm{b}} \pm 1.7$ & $90^{\mathrm{a}} \pm 2.9$ & $75^{\mathrm{b}} \pm 2.9$ & $25^{\mathrm{c}} \pm 2.8$ & $30^{\mathrm{c}} \pm 1.7$ & 7.8 \\
\hline 8. & $\begin{array}{l}\text { Cleaning and sanitizing work } \\
\text { surfaces after each task }\end{array}$ & $77^{\mathrm{a}} \pm 4.0$ & $43^{\mathrm{d}} \pm 1.7$ & $60^{\mathrm{bc}} \pm$ & $55^{\mathrm{c}} \pm 1.2$ & $65^{\mathrm{b}} \pm 2.9$ & 8.3 \\
\hline 9. & $\begin{array}{l}\text { Keeping restaurant and } \\
\text { equipment clean all time }\end{array}$ & $44^{\mathrm{c}} \pm 2.3$ & $55^{\mathrm{b}} \pm 2.8$ & $65^{\mathrm{a}} \pm 2.9$ & $66^{\mathrm{a}} \pm 3.5$ & $70^{\mathrm{a}} \pm 1.7$ & 8.6 \\
\hline 10. & $\begin{array}{l}\text { Food safety conditions (expiry } \\
\text { date, temperature, shape, smell } \\
\text { and flavor) clear }\end{array}$ & $90^{\mathrm{a}} \pm 3.5$ & $70^{\mathrm{c}} \pm 1.7$ & $80^{\mathrm{b}} \pm 1.7$ & $40^{\mathrm{d}} \pm 2.3$ & $20^{\mathrm{e}} \pm 1.2$ & 7.0 \\
\hline
\end{tabular}

Means followed by different subscripts within row are significantly different at the 5\% level

Regarding the food and safety procedures presented in the sailing restaurants in Egypt, the cooked fresh food was examined tracking the following results; $10 \%$ mentioned that it was excellent, $11 \%$ stated that it was good, $26 \%$ reported that it was neutral, $28 \%$ indicated that it was not accepted and $25 \%$ pointed out that it was poor.

Whereas, by the examination of the waiting time suitability, 12\% stated that it was excellent, $7 \%$ mentioned that it was acceptable, $25 \%$ reported that it was neutral, $27 \%$ said that it was not acceptable, and $30 \%$ stated that it was poor.

With reference to the immediate coverage of the cooked food, $17 \%$ stated that it was excellent, $18 \%$ mentioned that it was acceptable, $23 \%$ said that it was neutral, $22 \%$ reported that it was not acceptable and $20 \%$ declared that it was poor.

Regarding the usage of separate equipment for raw and cooked food, $18 \%$ said that it was excellent, $20 \%$ mentioned that it was acceptable, $28 \%$ stated that it was neutral, $45 \%$ reported that it was not acceptable and $18 \%$ mentioned that it was poor.

By examining whether the staff is wearing gloves while touching or serving food, $19 \%$ stated that it was excellent, $21 \%$ declared that it was acceptable, $25 \%$ mentioned that it was neutral, $17 \%$ said that it was not acceptable and $18 \%$ stated that it was poor. 
With reference to the usage of the staff of protective clothes and a cap (hair restraint) when touching or distributing unwrapped food, 19\% mentioned that it was excellent, 17\% stated that it was acceptable, $26 \%$ declared that it was neutral, $21 \%$ said that it was not acceptable and $17 \%$ mentioned that it was poor.

Whereas, by examining if the staff wears clean uniform when working in food service, $27 \%$ stated that it was excellent, $20 \%$ mentioned that it was acceptable, $25 \%$ said that it was neutral, $8 \%$ reported that it was not acceptable and $10 \%$ mentioned that it was poor.

Regarding cleaning and sanitizing work surfaces after each task, 26\% stated that it was excellent, $14 \%$ mentioned that it was acceptable, $20 \%$ reported that it was neutral, $18 \%$ stated that it was not acceptable and $22 \%$ reported that it was poor.

By the examination of the cleanness of the restaurant and its equipment all working time, $15 \%$ stated that it was excellent, $18 \%$ mentioned that it was acceptable, $22 \%$ said that it was neutral, $22 \%$ reported that it was not acceptable and $23 \%$ mentioned that it was poor

Regarding food and safety conditions of foods including expiry date, temperature, shape, smell, and flavor, $33 \%$ stated that it was excellent, $23 \%$ mentioned that it was acceptable, $27 \%$ reported that it was neutral, $13 \%$ stated that it was not acceptable and $7 \%$ reported that it was poor.

\section{Conclusion}

Based on the results it could be concluded that food safety application are poor due to the following

- Most of executive chefs, who supposed to be the leaders of kitchen department in floating restaurants, are holders of unspecialized education certificates. Moreover, not all of them developed their educational level with any scientific or academic background. Although the majority of assistant kitchen chefs are graduated from tourism and hotels educational associations, they are not holders of specialized certificates. The results were obtained through a questionnaire which was distributed forms and compilation of data.

- Most of the visited floating restaurants do not have food safety policy or even a written food safety operation standard since executive chefs ignore the significance of such system. Consequently, food safety practices executed haphazardly with no system.

- Floating restaurants chefs have poor food safety attitudes and practices. This is exemplified in the following critical food safety mistakes:

- No regular checking of incoming food items.

- No use of thermometer to check and control food temperature.

- Less use of protective clothing.

- No regular cleaning and sanitization of surfaces.

- No covering of cooked food that makes it exposed to insects and dust.

- Floating restaurants chefs have poor knowledge as they are unaware of the basic food safety information such as the following:

- The correct place of storing uncooked food in fridges

- Time taken for bacteria to multiply

- Factors leading to bacteria growth in food

- Causes of food contamination

- The kitchen staff needs training to be more responsive and sensitive to customer needs, thus providing services that are more efficient and effective. Staff ability to answer customers' quires is another issue to be considered by the restaurants' operators. In addition, the 
restaurant atmosphere can also be improved by ensuring cleanliness and favorable ambience with appropriate music and lighting.

- This study investigates customer perceptions of floating restaurants in Egypt and the key restaurant attributes affecting customer satisfaction and repeat patronage intention. Considering both the qualitative results, which are descriptive in nature, and quantitative results, which encompass mean scores, correlations and cross tabs that are statistical in nature, this study provides new insights for floating restaurant operators on how to improve the overall dining experience.

- The descriptive result reveals that patrons' perception towards service quality level provided was satisfactory in some aspects. However, the qualitative results indicated some problems with the service. This implies that more effort is needed to improve the service quality level of the restaurant.

\section{Recommendations}

\section{1- Recommendations Related to Food Safety Training Activities}

Food safety training programs, which are already provided by different training associations, should be supported with refreshment courses as well as monitoring and follow up agenda. This is to guarantee the continuation of the correct food safety application in floating restaurant establishments as well as to ensure that kitchen staff maintains the appropriate food safety.

\section{2- Recommendations Related to Authorized Associations}

The Ministry of Tourism has to issue a decree for specifying the food safety qualification of the executive chefs in floating restaurant establishments. For example, the executive chef must be a holder of a recognized food safety certificate or an accredited academic qualification in culinary or food production. This law will assure the food safety competence of executive chefs.

3- Furthermore, cooperation should be made between the Ministry of Tourism and Ministry of Health to provide free food safety manuals and booklets that cover the basic food safety issues and distributed to floating restaurant establishments.

4- Additionally, food and beverage managers should create food safety operational standards. It is recommended that these standards should be benchmarked to a number of floating restaurant' standards and, simultaneously, matching food safety conditions and circumstances.

\section{References}

Angelo, R, M. \& Vladimir, A, N. (2004), " Hospitality Today: an introduction.", fifth edition, Michigan, Educational Institute of the American Hotel \& Lodging Association.

Bateson, J, E., G., (1995), " Managing Services Marketing: Text and Readings.", Third edition, Fort Worth, USA, the Dryden press.

Bowen, J. (1996), " Relationship Marketing: a strategic perspective." In: Kotas, R., Teare, R., Logie, J., Jayawardena, C. \& Bowen, J. "The International Hospitality Business." London, Cassell.

Clayton, D.; Griffith, C.; Price, P. and Peters, A., (2002) Food Handlers' Beliefs and Self-reported Practices. International Journal of Environmental Health Research, 12(1):25-39.

Costello, C., Gaddis, T., Tamplin, M., \& Morris, W. (1997). Evaluating the effectiveness of two instructional techniques for teaching four food safety principles to quick service employees. Journal of Foodservice Systems, 10(1), 41-50.

Cushman, J.W., Shanklin, C.W., \& Niehoff, B.P. (2001). Hygiene practices of part-time student employees in a university foodservice operation. The Journal of the National Association of 
College \& University Food Services. Available at: http:/www.nacufs.org/resources/publications/journal_2001.pdf

Egyptian Tourism Board :Incidence of Foodborne Illness:, (2008) Centers for Disease Control, Food borne illness Web Page [Online], Available at: http://www.cdc.gov/Features/dsFood borne Illness

Finch, C., \& Daniel, E. (2005). Food safety knowledge and behavior of emergency food relief organization workers: Effects of food safety training intervention. Journal of Environmental Health, 67(9), 30-34.

Food and Agricultural Organization (FAO), (2001) Essential Safety Requirements for Street-Vended Foods, (revised edition), FAO Food and Nutrition Paper

Food and Drug Administration (FDA) (2004) FDA report on the occurrence of food borne illness risk factors in selected institutional foodservice, restaurant, and retail food store facility types. Food and Drug Administration

Gupta, S., Mclaughlin, E. \& Gomez, M. (2007) "Guest Satisfaction and Restaurant Performance" Cornell Hotel and Restaurant Administration Quarterly [Internet] Vol. 48, issue 3, PP. 284-298. Available from: < http://cqx.sagepub.com > [Accessed 26 April 2017].

Hensley, R, L. \& Sulek, J. (2007), " Customer Satisfaction with Waits in Multi-Stage Services," Managing Service Quality [Internet] Vol. 17, No. 2, PP. 152-173. Available from: $<$ http://www.emeraldinsight.com>[Accessed 01 April 2017]

Howes, M.; McEwen, S.; Griffiths, M. and Harris, L. (1996) Food Handler Certification by Home Study: Measuring Changes in Knowledge and Behavior, Dairy Food Environment Sanitation, 16(7), 737-744

Hoyer, W, D. and Maclnnis, D, J. (2007), “Consumer Behavior”, New York, Houghton Mifflin Company. P. 281.

Hui, M, K. \& Tse, D, K. (1996), " What to tell Consumers in Waits of Different Lengths: an integrative model of service evaluation" The journal of marketing [Internet] Vol. 60, No. 2, PP. 81-90. Available from: < http://www.jstor.org> [Accessed 01 April 2017].

Hwang, J. (2006), " An Analysis of Wait Time Satisfaction for Capacity Management in a Simulated Restaurant" Ph.D. thesis, The Pennsylvania State University, Available from: <http://proquest.umi.com/login> [Accessed 22 April 2017].

Kamra, K, K., Mill, R, C. \& Kaushil, S. (2002), "Hospitality Operations and Management", first edition, New Delhi, Wheeler Publishing p. 81.

Kotler, P., Bowen, J, T. and Maken, J, C., (2006), "Marketing for Hospitality and Tourism”, New Jersey, Pearson prentice hall.

Ladhari, R., Brun, I. \& Morales, M. (2008), " Determinants of Dining Satisfaction and Post- Dining Behavioral Intentions" International Journal of Hospitality Management, Vol. 27, PP. 563573.[Internet] Available from : < http://www.sciencedirect.com> [Accessed 30 April 2017]

Law, A, K, Y. \& Hui, Y, V.(2004), " Modeling Repurchases Frequency and Customer Satisfaction for Fast Food Outlets" International Journal of Quality \& Reliability Management, May, Vol. 21, No. 5, PP .545-563. Available from:<http://www.emeraldinsight.com> [Accessed 1 April 2017]

Lee, W. \& Lambert, C, U. (2000), " Impact of Waiting Time on Evaluation of Service Quality and Customer Satisfaction in Foodservice Operation," Journal of Foodservice, December, Vol.12, Issue 4, PP. 241-254. Available from: http://www3.interscience.wiley.com [Accessed 25 April 2017]

Lee, W. (2002), "The Effect of Waiting Time and Affective Reactions on Customers' Evaluation of Service Quality and Satisfaction in a Cafeteria Simulation" Ph.D. thesis, The Pennsylvania state university, Available from: <http://proquest.umi.com/login> [Accessed 23 April 2017].

Luby, S. P., Jones, J., \& Horan, J. (1993). A large Salmonellosis outbreak associated with a frequently penalized restaurant. Epidemiology and Infection, 110, 31-39. 
Maeda, H.,and Rheem, C.K. (2000). "Time-domain analyses of elastic response and second-order mooring force on a very large floating structure in irregular waves," Marine Structures, 13:279-299.

Maister, D, H. (1985), "The Psychology of Waiting Lines" [online]. Available from : http://davidmaister.com/articles/5/52 [Accessed 23 July 2011]

Maylor, H. (2001)," Strategic Quality Management" In: Moutinho, L. " Strategic Management in Tourism " New York, CABI publishing

McElroy, D. M., \& Cutter, C. N. (2004). Self-report changes in food safety practices as a result of participation in a statewide food safety certification program. Food Protection Trends, 24,150161.

Moan, T. (2004). "Safety of floating offshore structures" Proc. 9th PRADS Conference, Keynote lecture, PRADS Conference, Luebeck-Travemuende, Germany, September 12- 17, 2004

Nie, W. (2000), "Waiting: Integrating Social and Psychological Perspectives in Operations Management" Omega, December, Vol. 28, Issue 6, PP. 611-629. [Internet] Available from $:<$ http://www.sciencedirect.com> [Accessed 30 April 2017]

Nield, K., Kozak, M. \& LeGrys, G. (2000), " The Role of Foodservice in Tourist Satisfaction" International Journal of Hospitality Management, December, Vol. 19, No. 4, pp. 375-384.

Ohkawa, Y. and Kobayashi, K. (2003). "Effects of breakwaters on motions of an elastic floating plate in waves," International Journal of Offshore and Polar Engineering, 13(1), 43-51.

Parasuraman, A., Zeithaml, V.A. and Berry, L.L. (1985), "A Conceptual Model of Service Quality and Its Implications for Future Research”, Journal of Marketing, Vol. 49 No. 4, pp. 41-50.

Pilling, V. K., Brannon, L. A., Shanklin, C. W., Roberts, K. R., Barrett, B. B., \& Howells, A. D. (2008). Food safety training requirements and food handlers' knowledge and behaviors. Food Protection Trends, 28(3), 192-200.

Pizam, A. \& Ellis, T. (1999), " Customer Satisfaction and Its Measurement in Hospitality Enterprises" International Journal of Contemporary Hospitality Management, Vol. 11, No. 7, pp. 326- 339. Available from: <http://www.emeraldinsight.com> [Accessed 20 April 2017]

Roberts, K. R., Barrett, B. B., Howells, A. D., Shanklin, C. W., Pilling, V. K., \& Brannon, L. A. (2008). Food safety training and foodservice employees' knowledge and behavior. Food Protection Trends, 28(4), 252-260.

SAS (1999): Statistical Analysis System, SAS / STAT User's Guide. Release 6.03 Ed. SAS Institute, Cary, NC, 1028 p.

Sulek, J, M. \& Hensley, R, L. (2004), "The Relative Importance of Food, Atmosphere, and Fairness of Wait: the case of a full-service restaurant" Cornell Hotel and Restaurant Administration Quarterly, Vol. 45, Issue 3, PP. 235-247. Available from: < http://cqx.sagepub.com > [Accessed 30 April 2017]

Threevitaya, S. (2003), "Factors that Influenced the Decisions of Customers to dine at Selected Restaurants in Bangkok, Thailand" Master of Science degree in hospitality and tourism, university of Wisconsin.

Trooboff, S, K., Schwartz, R. \& Maeneill, D, J. (1995), "Travel Sales and Customer Service" Boston, Irwin Mirror Press.

Wade, D. (2006), "Successful Restaurant Management: from vision to execution" USA, Thomson. P. 229.

Waller, K. (1996), "Improving Food and Beverage Performance" first edition, Oxford, Butter worth Heinemann.

Wie, S. H., \& Strohbehn, C. H. (1997). The impact of a sanitation and food safety course on attitudes and knowledge of hospitality students. Hospitality and Tourism Educator, 9(2), 65-73. 